\title{
DINAMIKA KELIMPAHAN ORIBATIDA PADA AREA PERKEBUNAN KELAPA SAWIT DI KECAMATAN BAJUBANG BATANGHARI JAMBI
}

\section{Population Dynamics of Oribatid Mites in the Oilpalm Plantation Area at Bajubang Batanghari Jambi}

\author{
Yuni Lisafitri1)*, Rahayu Widyastuti2), dan Dwi Andreas Santosa ${ }^{2)}$ \\ 1) Alumni Program Studi Bioteknologi Tanah dan Lingkungan, Sekolah Pascasarjana IPB, J1. Raya Darmaga, \\ Gedung Andi Hakim Nasoetion Kampus IPB Darmaga Bogor 16680 \\ 2) Departemen Ilmu Tanah dan Sumberdaya Lahan, Fakultas Pertanian IPB, J1. Meranti Kampus IPB Darmaga \\ Bogor 16680
}

\begin{abstract}
Oribatids are one of the important fauna groups in the soil. They have an important role in decomposition of organic matter in the soil. The objection of this research was to study population dynamics of Oribatids through determining the abundance and diversity of Oribatids and to know the effect of environment factors on Oribatids in oilpalm plantation at Bajubang, Batanghari, Jambi. Soil and litter samples were taken from four different locations $(25 \mathrm{~m} x 25 \mathrm{~m})$ and from each locations three samples were taken from litter lanes and open lanes, respectively (the size was $16 x 16 \mathrm{~cm}$ with a depth of soil is $5 \mathrm{~cm}$ ). The samples were extracted using Kempson extractor. Identification of Oribatid was done to family level and the diversity of Oribatids was measured using Shannon's diversity index. Population dynamic of Oribatids showed a fluctuation in sampling periode. When rainfall increased $>200 \mathrm{~mm}$ did not followed by increasing of abundance and diversity (number of family) of Oribatid mites. When rainfall between 100 - $200 \mathrm{~mm}$ was optimal condition for Oribatids so abundance and diversity (number of family) of Oribatids increased. But, when rainfall $<100 \mathrm{~mm}$ especially in Februari 2014 (the lowest rainfall $1 \mathrm{~mm}$ ), abundance and diversity (number of family) of Oribatids was lowest (330 individual $\mathrm{m}^{-2}$; 7 family) compared to another months. It was assumed that Oribatids may migrate into the deep soil to avoid a harsh environmental condition. Abundance and diversity (number of family) of oribatids were significantly higher in litter lanes (4,560 individual $m^{-2} ; 25$ family) than in open lanes (1,570 individual $\mathrm{m}^{-2}$; 14 family). The availability of litter in the litter lanes was higher than in open lanes. In this research, There are 3 family that most abundance and always found on sampling periode, they are Scheloribatidae, Mycobatidae and Galumniidae.
\end{abstract}

Keywords: Abundance, diversity, oil palm plantation, Oribatids, soil fauna

\begin{abstract}
ABSTRAK
Oribatida merupakan salah satu kelompok fauna yang penting di dalam tanah. Mereka memiliki peran dalam dekomposisi bahan organik di tanah. Tujuan penelitian ini untuk mempelajari dinamika populasi Oribatida dengan mengukur kelimpahan dan keanekaragaman Oribatida pada area perkebunan kelapa sawit dan mengetahui pengaruh faktor lingkungan terhadap Oribatida pada area perkebunan kelapa sawit di Kecamatan Bajubang, Batanghari, Jambi. Contoh tanah dan serasah diambil dari empat lokasi yang berbeda $(25 \mathrm{~m} \mathrm{x} 25 \mathrm{~m})$ dan dari setiap lokasi diambil masing - masing tiga contoh tanah pada gawangan serasah dan gawangan hidup (berukuran 16 x $16 \mathrm{~cm}$, kedalaman $5 \mathrm{~cm}$ ). Sampel tersebut diekstrak menggunakan Kempson Extractor. Identifikasi Oribatida dilakukan sampai tingkat famili dan indeks keanekaragamannya ditentukan menurut Shannon's diversity index. Dinamika populasi Oribatida di area perkebunan kelapa sawit menunjukkan adanya fluktuasi pada periode pengambilan sampel. Fluktuasi tersebut bergantung dengan curah hujan setiap bulannya. Ketika curah hujan meningkat $>200 \mathrm{~mm}$ tidak diikuti dengan peningkatan kelimpahan dan keanekaragaman Oribatida. Ketika curah hujan antara $100-200 \mathrm{~mm}$ merupakan kondisi yang optimal bagi Oribatida sehingga kelimpahan dan keanekaragamannya meningkat. Namun, ketika curah hujan < 100 mm khususnya pada bulan Februari 2014 (curah hujan terendah 1 mm), kelimpahan dan keanekaragaman Oribatida (330 individu $\mathrm{m}^{-2} ; 7$ famili) terendah dibandingkan bulan lainnya. Oribatida diduga mengalami perpindahan ke lapisan tanah yang lebih dalam untuk menghindari kondisi lingkungan yang tidak menguntungkan di permukaan tanah. Kelimpahan dan keanekaragaman Oribatida (jumlah famili) secara signifikan lebih tinggi di Gawangan serasah (4,560 individu $\mathrm{m}^{-2} ; 25$ famili) dibandingkan di gawangan hidup (1,570 individu $\mathrm{m}^{-2} ; 14$ famili). Ketersediaan serasah di gawangan serasah lebih tinggi dibandingkan di gawangan hidup. Di dalam penelitian ini, terdapat 3 famili yang paling melimpah dan selalu ditemukan selama periode pengambilan sampel yaitu Scheloribatidae, Mycobatidae dan Galumniidae.
\end{abstract}

Kata kunci: Kelimpahan, keanekaragaman, perkebunan kelapa Sawit, Oribatida, fauna tanah 


\section{PENDAHULUAN}

Oribatida merupakan salah satu fauna utama yang memiliki peranan penting di tanah. Oribatida termasuk ke dalam kelompok mikroartropoda tanah yang merupakan subordo dari subkelas Acari. Oribatida memiliki lebih dari 9,000 spesies dengan jumlah famili sebanyak 172 (Krantz dan Walter, 2009). Oribatida merupakan kelompok saprophagus (pemakan alga, bakteri, yeast, fungi dan sisa tanaman) serta dapat berperan dalam distribusi spora fungi (Toluk dan Ayyildiz, 2011). Oribatida berkontribusi dalam dinamika unsur hara dengan membantu proses dekomposisi bahan organik. Oribatida memiliki peranan dalam memecah bahan organik menjadi ukuran yang lebih kecil dan kemudian dapat digunakan oleh mikrob decomposer.

Peranan Oribatida dalam dekomposisi bahan organik dipengaruhi oleh faktor - faktor lingkungan. Oribatida pada suatu ekosistem selalu hidup berinteraksi dengan organisme lain dan faktor-faktor lingkungannya. Tentunya interaksi tersebut akan mempengaruhi kelimpahan dan penyebaran Oribatida. Faktor-faktor lingkungan yang dapat mempengaruhi aktivitas Oribatida yaitu iklim (curah hujan, temperatur), tanah (kemasaman, kelembaban, temperatur, kandungan unsur hara), vegetasi serta cahaya matahari (Suin, 2006). Kelembaban dan temperatur menjadi salah satu faktor lingkungan utama yang mempengaruhi Oribatida. Temperatur berpengaruh dalam respirasi, pencernaan dan pertumbuhan Oribatida (Jordan, 2001). Perubahan kondisi lingkungan seperti perubahan kelembaban dan temperatur tanah dapat terjadi akibat perubahan curah hujan, lama penyinaran matahari dan temperatur udara. Perubahan tersebut akan mengubah kondisi habitatnya dan akan mempengaruhi Oribatida.

Oribatida merupakan salah satu mesofauna tanah yang sensitif terhadap perubahan lingkungan di habitatnya. Perubahan tersebut terjadi baik akibat aktivitas manusia maupun akibat perubahan cuaca yang ekstrim. Beberapa penelitian menunjukkan bahwa kepadatan Oribatida di tanah pada ekosistem alami (hutan) lebih tinggi ketika musim penghujan dibandingkan musim kemarau (Gergocs dan Hufnagel, 2009). Namun, pada ekosistem lainnya yang memiliki kelembaban yang sangat tinggi karena adanya penggenangan memiliki kelimpahan yang jauh lebih rendah. Widyastuti (2005) menunjukkan bahwa kelimpahan Oribatida rendah selama periode penggenangan di lahan sawah dengan jumlah antara 15 37 individu $\mathrm{m}^{-2}$.

Kelimpahan dan keanekaragaman yang tinggi serta sensitivitasnya terhadap perubahan lingkungan menjadi alasan Oribatida dijadikan sebagai mesofauna yang baik untuk menilai gangguan ekosistem (Swift dan Norton, 1998). Aktivitas manusia seperti aktivitas pertanian dapat menurunkan jumlah Oribatida di tanah. Penggunaan pupuk anorganik dan pestisida pada perkebunan kelapa sawit tentunya akan mempengaruhi Oribatida yang berada pada ekosistem tersebut. Oribatida akan menunjukkan respon terhadap perubahan kondisi habitatnya. Respon tersebut ditunjukkan dengan perubahan kepadatan kelimpahannya. Kelimpahan Oribatida pada ekosistem alami (hutan) sangat tinggi yaitu $>50,000$ individu $\mathrm{m}^{-2}$. Kultivasi lahan-lahan pertanian mengurangi kelimpahan hingga rata-rata 25,000 individu $\mathrm{m}^{-2}$ (Coleman et al., 2004).
Oribatida memiliki peranan yang penting di tanah khususnya dalam dekomposisi bahan organik. Perubahan curah hujan, temperatur dan kelembaban udara yang terjadi setiap bulannya di area perkebunan kelapa sawit dapat mempengaruhi perubahan kondisi di permukaan tanah dan serasah. Tanah dan serasah merupakan salah satu habitat bagi Oribatida. Adanya perubahan kondisi tersebut tentunya akan direspon oleh Oribatida yang sensitif terhadap perubahan lingkungan. Respon tersebut ditunjukkan dengan adanya perubahan kelimpahan Oribatida, maka perlu dipelajari bagaimana perubahan populasi Oribatida (kelimpahan dan keanekaragaman) di area perkebunan kelapa sawit di Kecamatan Bajubang, Kabupaten Batanghari, Provinsi Jambi.

\section{BAHAN DAN METODE}

Pengambilan contoh tanah dan serasah dilakukan di empat lokasi perkebunan rakyat (kelapa sawit) di Kecamatan Bajubang, Kabupaten Batanghari Jambi. Koordinat masing - masing plot yaitu $103^{\circ} 26^{\prime} 43.8^{\prime \prime}$ BT $01^{\circ}$ 90' 95" LS (Desa Bungku), 103 26' 62.7” BT 01 ${ }^{\circ} 88^{\prime}$ 16.2" LS (Pompa Air), $103^{\circ} 30^{\prime} 59.3^{\prime \prime}$ BT 01 ${ }^{\circ} 85^{\prime} 62.8^{\prime \prime}$ LS (Sungkai) dan $103^{\circ} 26^{\prime} 98.9 "$ BT $01^{\circ}$ 79' 59.6" LS (Singkawang). Ekstraksi mesofauna dilakukan di Laboratorium Tanah CRC EFForTS Project di Universitas Jambi. Perhitungan kelimpahan dan identifikasi Oribatida dilakukan di Laboratorium Bioteknologi Tanah serta Laboratorium Kimia dan Kesuburan Tanah, Departemen Tanah dan Sumberdaya Lahan, Fakultas Pertanian, Institut Pertanian Bogor.

Contoh tanah dan serasah diambil pada plot $(25 \mathrm{~m} \mathrm{x}$ $25 \mathrm{~m})$ di empat lokasi perkebunan dan dari setiap plot diambil 6 contoh tanah dan serasah (tiga contoh tanah dan serasah pada gawangan serasah/mati dan tiga contoh tanah dan serasah pada gawangan hidup) sehingga didapatkan 24 sampel (tanah dan serasah disatukan). Contoh tanah yang diambil berukuran $16 \times 16 \mathrm{~cm}$ dengan kedalaman $5 \mathrm{~cm}$. Sedangkan pengambilan contoh tanah komposit dilakukan untuk mengukur respirasi tanah. 24 contoh tanah dan serasah tersebut diekstraksi menggunakan Kempson Extractor untuk mengekstrak Oribatida. Oribatida yang telah didapatkan kemudian diidentifikasi dengan menggunakan stereomicroscope dan compound microscope sampai tingkat famili dengan mengacu pada Krantz dan Walter (2009) dan Balogh dan Balogh (1990).

Untuk menghitung kelimpahan dan keanekaragaman Oribatida ditetapkan sebagai berikut :

Jumlah Oribatida ditetapkan dengan rumus (Meyer, 1996)

Keterangan:

$$
\mathbf{I}=\frac{\text { IS }}{\mathbf{A}}
$$

I : jumlah individu $\mathrm{m}^{-2}$

IS : rata-rata jumlah individu contoh tanah

A : luas soil core $\left(\mathrm{m}^{2}\right)=$ panjang $\mathrm{x}$ lebar $=16 \times 16=256$ $\mathrm{cm}^{2}=0.0256 \mathrm{~m}^{2}$

Indeks keanekaragaman Shannon and Wiener

(Magurran, 2004) adalah :

$$
\mathbf{H}^{\prime}=-\sum_{i=1}^{s}(P i \ln P i)
$$


Keterangan :

$\mathrm{Pi}:$ ni/N (N : total jumlah individu ; ni : jumlah individu jenis ke i)

Data kelimpahan dan jumlah famili Oribatida diuji statistika dengan ANOVA dan uji Tukey HSD pada taraf $5 \%$ menggunakan software Statistica 7 for Windows untuk melihat perbedaan kelimpahan dan keanekaragaman Oribatida pada setiap bulan pengambilan sampel di area perkebunan kelapa sawit.

\section{HASIL DAN PEMBAHASAN}

\section{Dinamika Kelimpahan Oribatida}

Data curah hujan yang diambil dari Stasiun Klimatologi Muara Bulian, Kabupaten Batanghari, Jambi memperlihatkan curah hujan dari bulan November 2014 Mei 2014. Bulan November 2013 - Januari 2014 dan Maret - Mei 2014 termasuk bulan basah menurut Schmidht - Ferguson karena curah hujan tinggi mencapai $>100 \mathrm{~mm}$. Bulan November 2013, Desember 2013 dan April 2014 curah hujan >200 mm. Sedangkan Februari 2014 (1 mm) merupakan bulan kering karena curah hujan yang rendah $<60 \mathrm{~mm}$ (Tabel 1). Rata-rata suhu dan kelembaban udara selama waktu penelitian cenderung stabil.

Tabel 1. Data curah hujan, kelembapan dan temperatur udara di Kabupaten Batanghari Jambi

\begin{tabular}{|c|c|c|c|}
\hline Waktu & $\begin{array}{c}\text { Curah Hujan } \\
(\mathrm{mm})\end{array}$ & Kelembapan (\%) & $\begin{array}{c}\text { Temperatur } \\
\left({ }^{\circ} \mathrm{C}\right)\end{array}$ \\
\hline Nov-13 & 253 & 81 & 26.8 \\
\hline Des-13 & 229 & 81 & 26.8 \\
\hline Jan-14 & 135 & 81 & 25.8 \\
\hline Feb-14 & 1 & 83 & 26.7 \\
\hline Mar-14 & 174 & 81 & 27.0 \\
\hline Apr-14 & 240 & 81 & 27.0 \\
\hline Mei-14 & 164 & 81 & 27.0 \\
\hline
\end{tabular}

Oribatida merupakan kelompok fauna tanah yang paling banyak ditemukan pada contoh tanah dan serasah di setiap pengambilan sampel. Tabel 2 menunjukkan kelimpahan Oribatida pada area perkebunan kelapa sawit. Kelimpahan Oribatida di gawangan hidup dan di gawangan serasah berfluktuasi dengan pola yang relatif sama. Kelimpahan Oribatida di gawangan serasah lebih berfluktuasi dibandingkan dengan di gawangan hidup. Dinamika kelimpahan Oribatida yang terjadi selama waktu pengambilan sampel menunjukkan adanya perbedaan yang signifikan. Kelimpahan Oribatida pada bulan Februari 2014 (curah hujan sangat rendah $(1 \mathrm{~mm})$; temperatur $26.7^{\circ} \mathrm{C}$; kelembapan udara $83 \%$ ) menunjukkan nilai terendah baik di gawangan hidup (166 individu $\mathrm{m}^{-2}$ ) maupun di gawangan serasah (494 individu $\mathrm{m}^{-2}$ ). Rata-rata kelimpahan Oribatida di bulan Februari 2014 (330 individu $\mathrm{m}^{-2}$ ) berbeda secara signifikan dengan bulan Januari dan Mei 2014 (5,081 individu $\mathrm{m}^{-2}$ dan 4,847 individu $\mathrm{m}^{-2}$ ). Hal ini diduga karena kondisi habitat pada bulan Januari dan Mei lebih sesuai bagi Oribatida.
Tabel 2. Dinamika kelimpahan Oribatida di area perkebunan kelapa sawit Kecamatan Bajubang, Kabupaten Batanghari Jambi

\begin{tabular}{lccc}
\hline Waktu & \multicolumn{3}{c}{ Kelimpahan Oribatida (Individu m ${ }^{-2}$ ) } \\
\cline { 2 - 4 } & $\begin{array}{c}\text { Gawangan } \\
\text { hidup }\end{array}$ & $\begin{array}{c}\text { Gawangan } \\
\text { serasah/serasah }\end{array}$ & Rataan $^{* 1)}$ \\
\hline Nov-13 & 2,129 & 3,753 & $2,941 \mathrm{ab}$ \\
Des-13 & 887 & 4,823 & $2,855 \mathrm{ab}$ \\
Jan-14 & 2,704 & 7,458 & $5,081 \mathrm{~b}$ \\
Feb-14 & 166 & 494 & $330 \mathrm{a}$ \\
Mar-14 & 1,885 & 5,739 & $3,812 \mathrm{ab}$ \\
Apr-14 & 692 & 2,483 & $1,588 \mathrm{ab}$ \\
Mei-14 & 1,781 & 7,169 & $4,847 \mathrm{~b}$ \\
\hline Rataan ${ }^{* 2)}$ & $1,570 \mathrm{a}$ & $4,560 \mathrm{~b}$ & \\
\hline Keterangan : & ANOVA dan Uji Tukey ${ }^{* 1)} \mathrm{F}_{(6: 42)}=15.71^{* * *} ;{ }^{* 2)} \mathrm{F}_{(1: 42)}=$ \\
& $34.39 * * *:$ transformasi data $(\log 10+1)$ dilakukan
\end{tabular}

Kelimpahan Oribatida yang rendah di bulan Februari 2014 diduga karena rendahnya intensitas curah hujan pada bulan Februari sehingga mempengaruhi kelembaban di permukaan tanah. Perubahan kelembaban tersebut diduga mempengaruhi kelimpahan Oribatida. Selain itu, pada bulan Februari 2014 telah dilakukan pemberian herbisida di dua lokasi pengambilan sampel sehingga hal ini juga menjadi salah satu penyebab rendahnya kelimpahan Oribatida. Gbarakoro dan Zabbey (2013) menyatakan bahwa pemberian herbisida menyebabkan penurunan jumlah mesofauna tanah salah satunya Oribatida dibandingkan dengan kontrol.

Contoh tanah untuk estimasi Oribatida diambil sampai kedalaman $5 \mathrm{~cm}$. Hal ini dikarenakan Oribatida dan fauna tanah lainnya membutuhkan serasah sebagai sumber makanan (Krantz dan Walter, 2009; Wallwork, 1976) sehingga Oribatida dan fauna tanah lainnya akan lebih banyak ditemukan di lapisan atas tanah. Kondisi lingkungan di permukaan tanah yang kurang menguntungkan menyebabkan beberapa Oribatida mengalami perpindahan/migrasi ke tempat lain yang memiliki kondisi lingkungan yang lebih menguntungkan, misalnya masuk ke lapisan tanah yang lebih dalam. Selain itu beberapa Oribatida diduga mengalami kematian akibat kondisi yang kurang menguntungkan.

Menurut Urhan et al. (2008) Acari (termasuk Oribatida) dapat berpindah secara vertikal, baik ke atas (lapisan serasah organik) atau ke dalam tanah. Acari masih ditemukan sampai pada kedalaman $15 \mathrm{~cm}$ dari permukaan tanah. Mereka berpindah diduga karena untuk menghindari kondisi lingkungan yang kurang menguntungkan di permukaan tanah dalam hal ini berkaitan dengan temperatur dan kelembapan tanah. Onen dan Koç (2011) menambahkan di daerah beriklim sedang, pada musim gugur perpindahan Oribatida dari bawah ke atas akibat penurunan temperatur tanah dan peningkatan kelembapan tanah. Sedangkan pada musim semi, terjadi perpindahan dari atas ke bawah. kelembapan tanah dan temperatur tanah memiliki pengaruh yang paling signifikan dalam perpindahan ini. Bedano et al. (2005) melakukan penelitian di Argentina (subtropis). Hasil penelitian didapatkan bahwa adanya dinamika kelimpahan Oribatida pada periode pengambilan sampel dan kelimpahan terendah $\left(85\right.$ individu $\mathrm{m}^{-2}$ ) terjadi pada saat curah hujan $<50 \mathrm{~mm}$ dan temperatur udara $20^{\circ} \mathrm{C}$. 


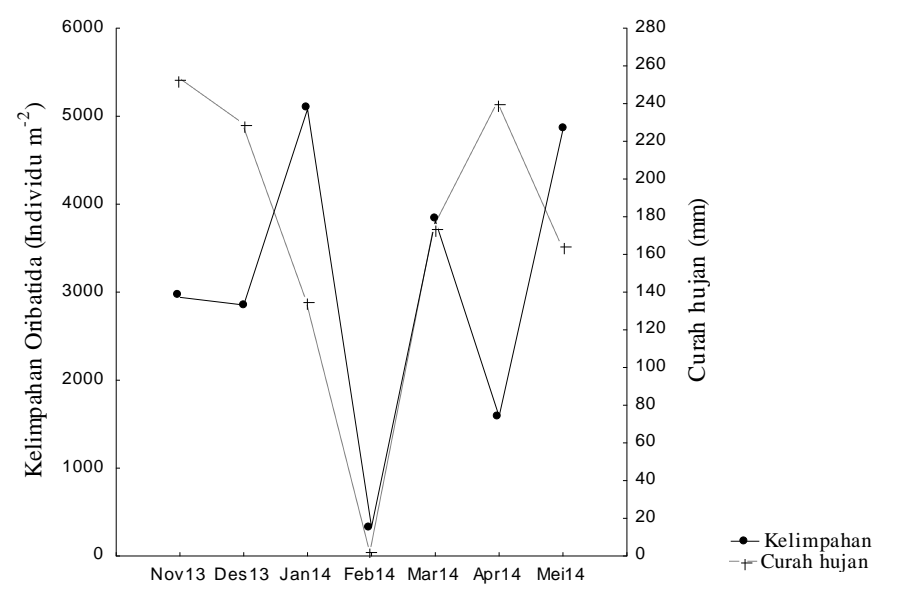

Gambar 1. Curah hujan dan rataan kelimpahan Oribatida dari gawangan hidup dan mati di area perkebunan kelapa sawit Kecamatan Bajubang Kabupaten Batanghari Jambi

Gambar 1 menunjukkan bahwa rata-rata kelimpahan Oribatida menurun tajam ketika curah hujan $<100 \mathrm{~mm}$, kelimpahan Oribatida meningkat ketika curah hujan 100 - $200 \mathrm{~mm}$ dan kelimpahan Oribatida menurun ketika curah hujan meningkat $>200 \mathrm{~mm}$. Peningkatan curah hujan $>200 \mathrm{~mm}$ tidak diikuti dengan peningkatan kelimpahan Oribatida. Namun, ketika curah hujan sangat rendah $<100 \mathrm{~mm}$ jumlah Oribatida yang ditemukan pada kondisi tersebut juga sangat rendah. Hal ini berkaitan dengan ketahanan masing - masing Oribatida terhadap kelembaban habitatnya. Tidak semua Oribatida mampu bertahan di kondisi habitat yang kelembabannya rendah. Curah hujan 100 - 200 mm merupakan kondisi yang paling optimal bagi Oribatida.

Perbedaan signifikan juga terjadi di gawangan hidup dan gawangan serasah. Kelimpahan Oribatida di gawangan serasah lebih tinggi dibandingkan dengan di gawangan hidup. Oribatida memiliki peranan dalam dekomposisi bahan organik sehingga Oribatida akan banyak ditemukan di habitat yang memiliki bahan organik yang tinggi (Coleman et al., 2004). Wallwork (1976) menyatakan bahwa keanekaragaman fauna tanah seperti Acari (Oribatida), Collembola dan nematoda tergantung pada ketersediaan seresah (bahan organik) karena itu menjadi sumber makanan bagi fauna tersebut.

Gawangan serasah memiliki serasah yang lebih banyak karena tanahnya ditutupi oleh tumpukan pelepah kelapa sawit. Pelepah tersebut merupakan sumber bahan organik dengan rata-rata ketebalan $2.15 \mathrm{~cm}$. Rata-rata respirasi tanah di gawangan serasah sebesar $27.90 \mathrm{mgCO}_{2}$ hari $^{-1}$ yang lebih tinggi dibandingkan gawangan hidup sebesar $23.78 \mathrm{mgCO}_{2}$ hari $^{-1}$. Respirasi tanah menunjukkan aktivitas biologi di dalam tanah salah satunya aktivitas mikrob, tingginya aktivitas biologi menunjukkan tingginya jumlah mikrob di tanah. Aktivitas mikrob di gawangan serasah lebih tinggi dibandingkan dengan di gawangan hidup sehingga jumlah mikrob di gawangan serasah lebih tinggi dibandingkan dengan di gawangan hidup. Aktivitas mikrob di tanah salah satunya mendekomposisi bahan organik. Oribatida juga berperan di dalam dekomposisi bahan organik karena Oribatida diketahui sebagai pemakan serasah tanaman juga sebagian Oribatida diketahui sebagai pemakan fungi.

\section{Dinamika Keanekaragaman Oribatida}

Tabel 3 dan Gambar 2 menunjukkan dinamika keanekaragaman Oribatida (jumlah famili) pada area perkebunan kelapa sawit. Jumlah famili Oribatida baik di gawangan serasah maupun gawangan hidup lebih banyak pada bulan Januari, Maret dan Mei 2014 dibandingkan dengan bulan lainnya. Rata - rata jumlah famili Oribatida yang ditemukan pada bulan Januari (24 famili), Maret (26 famili) dan Mei (24 famili) lebih tinggi secara signifikan dibandingkan dengan bulan Februari (7 famili) dan April (15 famili). Jumlah famili di bulan Februari merupakan jumlah terendah dibandingkan bulan lainnya. Ini terjadi baik di gawangan hidup maupun gawangan serasah.

Rata-rata jumlah famili di gawangan serasah (25 famili) lebih banyak secara signifikan dibandingkan di gawangan hidup (14 famili). Ketersediaan sumber makanan berupa serasah/pelepah dari kelapa sawit di gawangan serasah lebih disukai oleh Oribatida sehingga famili Oribatida lebih banyak ditemukan pada kondisi habitat tersebut. Serasah merupakan sumber makanan utama bagi Oribatida sehingga keberadaan bahan organik (serasah) sangat mempengaruhi Oribatida.

Tabel 3. Dinamika keanekaragaman Oribatida di area perkebunan kelapa sawit Kecamatan Bajubang Kabupaten Batanghari Jambi

\begin{tabular}{cccccc}
\hline \multirow{2}{*}{ Waktu } & \multicolumn{3}{c}{ Jumlah famili } & \multicolumn{2}{c}{ Shannon's index } \\
\cline { 2 - 6 } & Gawangan hidup & Gawangan serasah & Rataan $^{* 1)}$ & Gawangan hidup & Gawangan serasah \\
\hline Nov-13 & 15 & 21 & $18 \mathrm{bc}$ & 1.39 & 1.52 \\
Des-13 & 15 & 30 & $22 \mathrm{bc}$ & 1.24 & 2.15 \\
Jan-14 & 17 & 30 & $24 \mathrm{c}$ & 1.36 & 2,06 \\
Feb-14 & 5 & 8 & $7 \mathrm{a}$ & 0.50 & 0.78 \\
Mar-14 & 19 & 32 & $26 \mathrm{c}$ & 1.49 & 2.01 \\
Apr-14 & 11 & 19 & $15 \mathrm{~b}$ & 1.07 & 1.60 \\
Mei-14 $_{\text {Rataan }}{ }^{2)}$ & 17 & 31 & $24 \mathrm{c}$ & 1.47 & 2.10 \\
\hline
\end{tabular}

Keterangan : ANOVA dan Uji Tukey $* 1) \mathrm{F}(6: 42)=15.73 * * * ; * 2) \mathrm{F}(1: 42)=33.30 * * *$ 


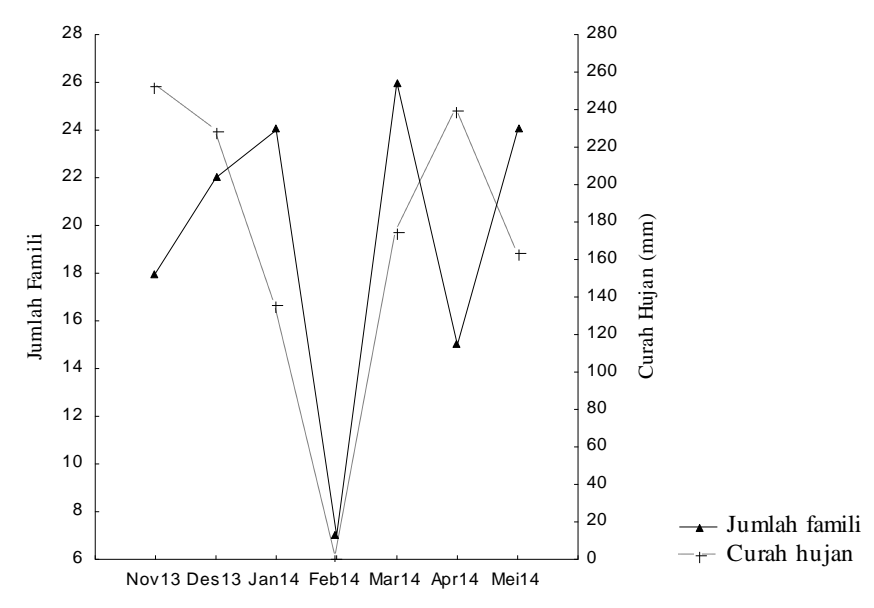

Gambar 2. Dinamika jumlah famili Oribatida di area perkebunan kelapa sawit Kecamatan Bajubang Kabupaten Batanghari Jambi

Pola dinamika jumlah famili Oribatida relatif sama dengan dinamika kelimpahan Oribatida. Hal ini menunjukkan bahwa rendahnya kelimpahan Oribatida juga diikuti dengan rendahnya jumlah famili. Namun, kelimpahan tertinggi tidak diikuti dengan jumlah famili terbanyak. Beberapa famili yang dominan jumlahnya menurun pada saat terjadinya perubahan cuaca. Bahkan beberapa tidak ditemukan pada saat curah hujan sangat rendah $(1 \mathrm{~mm})$. Hal ini mengindikasikan bahwa habitat di area perkebunan kelapa sawit tidak bisa memberikan kondisi yang nyaman bagi beberapa famili Oribatida pada saat terjadinya perubahan cuaca tersebut. Gambar 2 menunjukkan fluktuasi dari rataan jumlah famili Oribatida pada waktu pengambilan sampel dan fluktuasi curah hujan. Peningkatan curah hujan dengan intensitas >200 mm tidak diikuti dengan peningkatan jumlah famili Oribatida. Namun, ketika curah hujan sangat rendah $<100 \mathrm{~mm}$ famili Oribatida yang ditemukan pada kondisi tersebut juga sangat sedikit. Hal ini berkaitan dengan ketahanan Oribatida terhadap perubahan kelembaban di habitatnya. Tidak semua famili Oribatida mampu bertahan di kondisi habitat yang kelembabannya rendah. Curah hujan 100 $200 \mathrm{~mm}$ merupakan kondisi yang paling optimal bagi Oribatida untuk berkembang. Banyak famili yang ditemukan pada kondisi dengan curah hujan tersebut.

Indeks Shannon merupakan suatu perhitungan untuk mengetahui keanekaragaman Oribatida. Tabel 3 menunjukkan indeks keanekaragaman di gawangan serasah dan gawangan hidup. Indeks keanekaragaman Shannon pada bulan Februari 2014 menunjukkan nilai terendah. Seperti yang terjadi di gawangan hidup, pola yang sama juga terjadi di gawangan serasah. Berdasarkan hal tersebut dapat diketahui bahwa selain sumber makanan dalam hal ini bahan organik dan mikrob, curah hujan yang berkaitan dengan kelembaban tanah juga menjadi faktor yang mempengaruhi keanekaragaman Oribatida. Nilai indeks Shannon pada bulan Februari 2014 tersebut termasuk kategori keanekaragaman rendah.

Magurran (2004) menyatakan jika nilai indeks Shannon $<1.5$ merupakan keanekaragaman rendah artinya keanekaragaman dari famili Oribatida yang ada di habitat tersebut rendah, antara 1.5 - 3.5 termasuk keanekaragaman sedang dan jika >3.5 maka Oribatida tersebut memiliki keanekaragaman yang tinggi. Nilai indeks Shannon Oribatida di gawangan serasah berkisar antara $0.78-2.15$ dan di gawangan hidup $0.50-1.47$. Nilai indeks Shannon di gawangan serasah cenderung lebih tinggi dibandingkan di gawangan hidup. Hal ini tentunya dikarenakan di gawangan serasah ketersediaan sumber makanan lebih banyak dibandingkan di gawangan hidup sehingga jumlah famili yang ditemukan lebih banyak. Namun, keanekaragaman famili Oribatida di area perkebunan sawit bervariasi dari rendah sampai sedang. Pada iklim yang sama, kelimpahan dan keanekaragaman Oribatida di ekosistem hutan lebih tinggi dari area yang dipengaruhi aktivitas pertanian (Gergocs dan Hufnagel, 2009).

Semua Oribatida yang ditemukan telah berhasil diidentifikasi. Oribatida yang telah ditemukan dikelompokkan ke dalam 25 superfamili dan 34 famili. Jumlah famili yang didapat dalam penelitian ini sebanyak 34 dari 172 famili oribatida yang telah ditemukan di dunia sebelumnya (Krantz dan Walter, 2009). Pada penelitian ini, Scheloribatidae, Galumnidae dan Mycobatidae (Gambar 3) ditemukan lebih banyak dibandingkan famili yang lain dengan rata - rata kelimpahan Scheloribatidae sebanyak 760 individu $\mathrm{m}^{-2}$. Sedangkan rata - rata kelimpahan Galumnidae sebanyak 672 individu $\mathrm{m}^{-2}$ dan Mycobatidae sebanyak 514 individu $\mathrm{m}^{-2}$. Scheloribatidae banyak ditemukan di tanah dan serasah bahkan di mikrohabitat seperti di batang tanaman, pelepah tanaman, lichen, lumut dan banyak tempat lainnya. Begitu pula dengan Galumniidae daerah penyebarannya luas (Krantz dan Walter, 2009). Tingginya kelimpahan Scheloribatidae dan Mycobatidae akan membantu proses dekomposisi serasah karena baik Scheloribatidae maupun Mycobatidae merupakan pemakan serasah tanaman dan fungi. Cepatnya dekomposisi bahan organik maka akan mempercepat penyediaan unsur hara yang dibutuhkan tanaman kelapa sawit.

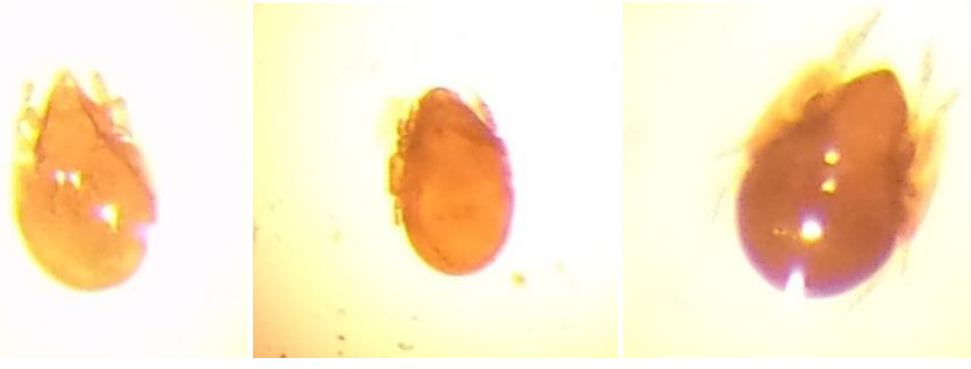

Gambar 3. Contoh famili Scheloribatidae, Mycobatidae dan Galumnidae (berurutan kiri-kanan) 


\section{SIMPULAN}

Populasi Oribatida pada area perkebunan kelapa sawit menunjukkan fluktuasi selama periode pengambilan sampel baik di gawangan serasah maupun di gawangan hidup. Fluktuasi tersebut bergantung dengan curah hujan setiap bulannya. Ketika curah hujan $<100$ mm khususnya pada bulan dengan curah hujan yang sangat rendah (Februari 2014, curah hujan $1 \mathrm{~mm}$ ), kelimpahan dan keanekaragaman Oribatida rendah pula. Namun, ketika curah hujan $>200 \mathrm{~mm}$ tidak diikuti dengan peningkatan kelimpahan dan keanekaragaman Oribatida. Kondisi dengan curah hujan 100 - 200 mm merupakan kondisi yang paling optimal bagi Oribatida sehingga kelimpahan dan keanekaragamannya meningkat. Kelimpahan dan keanekaragaman Oribatida (jumlah famili) di gawangan serasah lebih tinggi dibandingkan di gawangan hidup. Populasi Oribatida dipengaruhi bahan organik. Scheloribatidae, Mycobatidae dan Galumniidae merupakan famili yang kelimpahannya paling banyak ditemukan di area perkebunan kelapa sawit di Kecamatan Bajubang Kabupaten Batanghari Jambi.

\section{UCAPAN TERIMA KASIH}

Terima kasih penulis ucapkan kepada CRC Ecological and Socioeconomic Function of Tropical Lowland Rainforest Transformation System (Sumatera, Indonesia) atas berbagai dukungan materil untuk pelaksanaan penelitian.

\section{DAFTAR PUSTAKA}

Balogh, J. and P. Balogh. 1990. Oribatid Mites of The Neotropical Region I-II. Elsevier Science Publishing, USA. 335 pp.

Bedano, J.C., M.P. Cantú, and M.E. Doucet. 2005. Abundance of soil mites (Arachnida: Acari) in a natural soil of Central Argentina. Zoological Studies, 44: 505-512.

Coleman, D.C., D.A. Crossley, and J.P.F. Hendrix. 2004. Fundamentals of Soil Ecology. $2^{\text {nd }}$ Ed. Elsevier Academic Press, USA. 386 pp.

Gbarakoro, T.N. and N. Zabbey. 2013. Soil mesofauna diversity and responses to agro-herbicide toxicities in rainforest zone of the Niger Delta, Nigeria. Appl. J. Hygiene., 2: 01-07. doi: 10.5829/ idosi.ajh.2013.2.1.81205.
Gergocs, V. and L. Hufnagel. 2009. Aplication of Oribatid mites as indicators (review). Ecol. environ. Research., 7: 79-98.

Jordan, M.E. 2001. Population dynamics of Oribatid mites (Acari: Oribatida) on horse pastures of North Central Florida [Disertasi]. University of Florida.

Krantz, G.W. and D.E. Walter. 2009. A Manual of Acarology. $3^{\text {st }}$ Ed. Texas Tech University Press, USA. p 430-564.

Magurran, A.E. 2004. Measuring Biological Diversity. Blackwill Publishing, Maiden.

Meyer, E. 1996. Mesofauna. In E. Schinner, R. Ohlinger, E. Kandeler, and R. Margesin (Eds). Methods in Soil Biology. Springer-Verla, Berlin. p. 343.

Onen, O. and K. Koç. 2011. Seasonal and vertical distribution of Acarina fauna of grassland. CUJSE, 8: $277-289$.

Suin, N.M. 2006. Ekologi Fauna Tanah. Ed ke - 3. Bumi Aksara. Jakarta.

Swift, F.S. and R.A. Norton. 1998. Preliminary Report on Oribatid Mite (Acari: Oribatida) Diversity in the Hawaiian Islands. Bishop Museum Press, Hawai. p $1-9$.

Toluk, A. and N. Ayyildiz. 2011. Contributions to the Turkish Oribatid fauna (Acari: Oribatida) from Bolu province. Turk J Zool., 35: 63-70.

Urhan, R., Y. Katılmış, and A.Ö. Kahveci. 2008. Vertical distribution of soil mites (Acari) in Dalaman (Muğla prov.-Turkey). Munis Ento. Zool. J., 3: 333341.

Wallwork, J.A. 1976. The Distribution and Distribusy of Soil Fauna. Academic Press, New York. 355 pp.

Widyastuti, R. 2005. Population dynamics of microarthropods (Oribatida and Collembola) in rainfed paddy field ecosystem in Pati, Central Java. J. Tanah Lingk., 7: 11-14. 